\title{
InVestigation on Reducing Chromium Quantity in Chromium CONTAINING WASTES OF LEATHER INDUSTRY USING OYSTER MUSHROOM (Pleurotus Ostreatus)
}

\author{
Eser Eke Bayramoğlu ${ }^{1 *}$, Anıl Özçelik², Mehmet Çetin ${ }^{3}$, Erkan Eren ${ }^{4}$ \\ 1,2 Department of Leather Engineering, Faculty of Engineering, Ege University, 35100 Bornova-Izmir, Turkey \\ 3,4 Bergama Technicial and Bussiness Collage, Mushroom Programme, Ege University, Bergama-Izmir, Turkey
}

Abstract. In the leather industry, the shaved wastes after the wet blue phase, which are exposed by the shaving process, are one of the substances that cause environmental pollution for the leather industry. Most of the time, these wastes can be buried and may cause serious environmental pollution. In this study, wet blue shaved wastes to be mineralized to chromium and so prevented oxidise to $\mathrm{Cr}(\mathrm{VI})$ by using oyster mushrooms (Pleurotus ostreatus) .Wet blue shaved wastes were mixed with $0,5 \%, 1 \%, 1,5 \%$ and $2 \%$ doses into the growth medium. After the oyster mushroom growth, the consuming of chromium from the growth media and chromium content that uptaken by the mushroom were investigated with in House Method/ICP-MS.

\section{Introduction}

Nowadays, pollution in different steps of production in many industrial branches causes serious irremediable problems. [Yılmaz and Özgün, 2016]. Industrial production can be considered as the main reason of global warming, water pollution, air pollution and soil pollution [Ünal and Yılmaz, 2015].

There are many chemicals used in leather industry that cause pollution. Chromium is one of them and it is the most preferred tanning agent in leather industry. $80-90 \%$ of leather tanning is performed by $\mathrm{Cr}$ (III) salt [European Commission, 2013]. At the end of the chromium tanning, leathers are waited for the chemical reaction to continue. The leathers that become wet blue are shaved for the thickness adjustment. Wet blue shaved waste is one of the biggest factors that cause pollution in leather industry. Commercially, their biological and chemical treatments are endeavored; however, they are not fully succeeded. High amount of chromium is present in shavings. In many countries, these shavings are buried to the ground and ignored but they might cause severe health issues in the future. Due to toxic $\mathrm{Cr}$ (IV) and toxic gas outlet, removal of the shavings by burning is not recommended (http://www.mneproje.com/public/website/news/derisanayinde-krom-geri-kazanimi 20180924031547.pdf).

Chromate and chromate compounds can be used by plants and they can infiltrate through the deep soil layers causing the pollution in water resources. Chromates can be absorbed to the positively charged soil particles in less amount and they are prevented from convection to the atmosphere. However, unregulated storage of solid wastes containing chromium cause increment of the chromium concentration in soil and cause pollution in water resources [Environmental and Water Resources Institute (U.S.)., 2004].

When the waste produced during production or after production in leather industry which contains chromium is buried and if the burying area is not insulated enough, the filtration, transportation or mixing of theses wastes to the soil is inevitable. $\mathrm{Cr}$ (III) present in the leather is oxidized to $\mathrm{Cr}(\mathrm{VI})$ in the nature and creates great problems for being carcinogenic. 
Table 1. Evaluation of $\mathrm{Cr}(\mathrm{III})$ and $\mathrm{Cr}$ (IV) from the point of human health. (IULTCS, IUR-1, August 2013)

\begin{tabular}{|l|l|l|}
\hline \multirow{3}{*}{$\mathrm{Cr}(\mathrm{III})$} & Sensitivity & Does not create sensitivity (no sensitization) \\
\cline { 2 - 3 } & Acute Toxicity & No harmful or toxic related to impact amount and compound \\
\cline { 2 - 3 } & Carcinogen & Is not included on CMR list \\
\hline \multirow{3}{*}{$\mathrm{Cr}(\mathrm{VI})$} & Sensitivity & Does create sensitivity \\
\cline { 2 - 3 } & Acute Toxicity & Toxic \\
\cline { 2 - 3 } & Carcinogen & Carcinogen and Mutagen \\
\hline
\end{tabular}

It has been reported that $\mathrm{Cr}$ (III) is generally not including any risk [REACH report Annex XV, Chapter B.5.8 (ECHA 2011)]. $\mathrm{Cr}$ (VI) salt is not used in leather processing however $\mathrm{Cr}(\mathrm{VI})$ can be observed on finished leathers and this is not an intended feature [Bayramoğlu et al., 2012]. For instance, pH increase during neutralization causes the oxidation of $\mathrm{Cr}$ (III) to $\mathrm{Cr}(\mathrm{VI})$ or the drying the leather provides a backdrop for the formation of $\mathrm{Cr}$ (VI) [European Commission, 2013].

Discharge of heavy metals to the earth and water without disintegration is very important. It cannot be divided to non-toxic forms and leaves therefore a lasting effect on the ecosystem. Most of them are toxic even in very low concentrations. Arsenic, cadmium, chromium, copper, lead, mercury, selenium, silver, zinc, etc. are not only cytotoxic but also carcinogenic and mutagenic in the nature. This fact is clearly observed on several reports which show harmful effects of heavy metals on human health [Shukla et al., 2017].

We have to find effective, cheap and practical solution proposals for the removal of waste chromium without harming the environment if we want to use chromium as tanning material in leather production. It is required that chromium should be disintegrated before turning out to Chromium (IV) at that the quantity of chromium in the environment should be decreased. Bioremediation, in this context, is an innovative and promising methodology for the removal of heavy metal. Microorganisms, since they have developed new strategies to remain alive in environments including heavy metals, have adapted themselves to various detoxification mechanisms such as biosorption, bioaccumulation, biotransformation and biomineralization. They can thus make ex situ or in situ bioremediation.

Organisms which are mostly used on biological treatments in the scope of waste and environment technology are white rot fungi [Yeşilada, 1995]. Disintegration feature of white rot fungi is determined through various researches. They occupy an important and privileged place due to their characteristics. It is known that white rot fungi included in Basidiomycetes group, play a role in the elimination of environmental pollution shown up due to dense industrial activity, and the oxidation of organic compounds possessing very different molecular structures, together with various enzymes they synthesize, ie: lignin peroxidase (LIP), peroxidase related to manganese (MnP), to begin with laccase (lak) enzyme [Kunamneni et al., 2008; Pease et al., 1991].

Wood destroying Pleurotus ostreatus are saprophytic fungi. Easy development and yield on organic materials including lignin and cellulose without requiring any fermentation due to their strong mycelium structure allow the use of different industrial and agricultural wastes in the cultivation of Pleurotus ostreatus [Kurt, 2008]. Pleurotus ostreatus is resistant to toxic chemicals existing in the nature. It possesses a very strong oxidative biodecomposition potential.

We have tried in this research to show that white rot fungus will mineralize chromium wastes within its body and make them harmless and that the chromium can be decomposed without being oxidized to $\mathrm{Cr}(\mathrm{VI})$. Chromium on elementary level does not have any risk for human health is shown on Table 1 [IULTCS, 2013]. Leather wastes with chromium are mixed to the specially prepared compost in the research and chromium quantity existing in the compost before fungus inoculating and after fungus development and chromium quantity transferred to the fungus fruiting body are observed. Besides, impacts of chromium on the development and yield of fungus are also examined. 


\section{Material and Method}

\subsection{Material}

Wheat straw and wheat bran to be utilized in the research are provided from local suppliers and chromium added leather shaving wastes from "Lider Leather Tannery" located in Menemen Leather Free Zone (Figure 1).

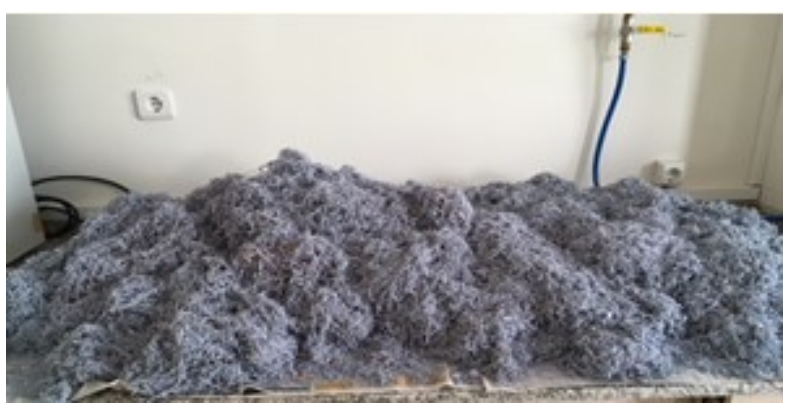

Figure 1. Shaving wastes containing chromium.

Sypra PL 28 (Pleurotus ostreatus) type mycelium is used in the test and is provided from the importer company "OPE Agriculture".

\subsection{Method}

Nitrogen content of shaving wastes containing chromium is determined through Kjeldhal Method [Standard Methods, 1995].

\subsubsection{Assembly of Tests}

\subsubsection{Preparation of Growing Environments}

Wheat straw (WS) is used as basic material in the research, and wheat bran (WB) and leather shaving wastes containing chromium ( $\mathrm{Cr}$ ) are used as additives. Mixture rates and codes of growing environments used in the research are given on Table 2 .
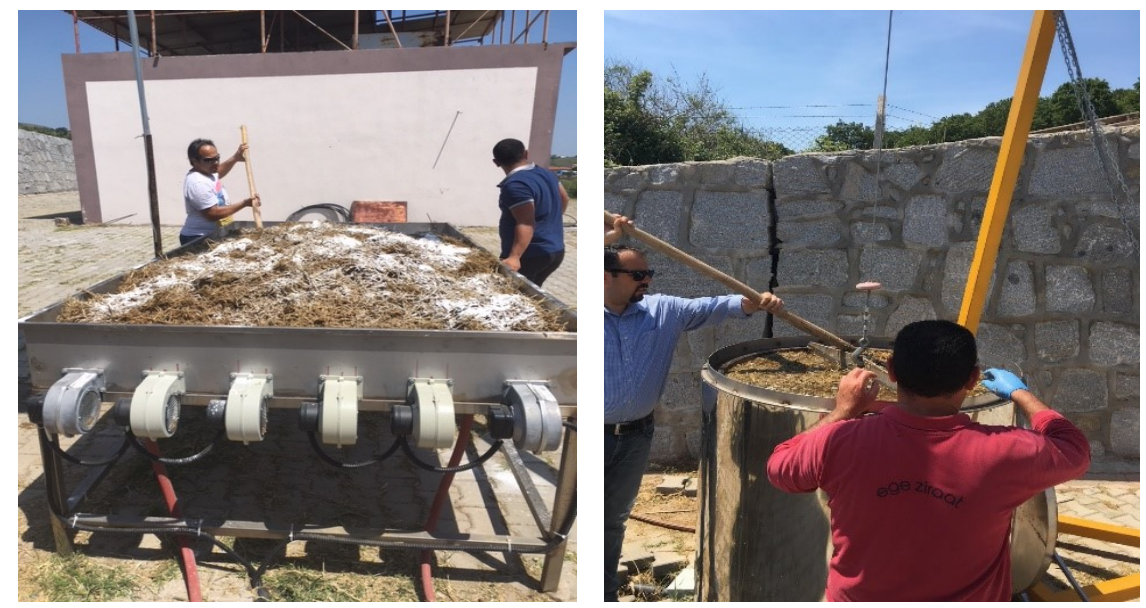

Figure 2. Preparation of Compost used on Tests.

Substrate prepared from the mixture of wheat straw and wheat bran (WS80+WB20) is used as the admixture $(\mathrm{C})$ in the research. Leather shaving wastes containing chromium mixed in 4 different rates $(0,5 \%, 1 \%, 1,5 \%$ and $2 \%)$ with wheat straw and wheat bran are used as control compost. 
Table 2. Mixture substrate contents.

\section{Compost Mixture Rates}

Wheat Straw (80\%) + Wheat Bran (20\%) (Mixture)

$0,5 \% \mathrm{Cr}+99,5 \%$ Mixture ( $80 \%$ wheat straw $+20 \%$ wheat bran)

$1 \% \mathrm{Cr}+99 \%$ Mixture ( $80 \%$ wheat straw $+20 \%$ wheat bran)

$1.5 \% \mathrm{Cr}+98.5 \%$ Mixture ( $80 \%$ wheat straw $+20 \%$ wheat bran)

$2 \% \mathrm{Cr}+98 \%$ Mixture ( $80 \%$ wheat straw $+20 \%$ wheat bran)
Code

Control (WS80+WB20)

$0,5 \% \mathrm{Cr}$

$1 \% \mathrm{Cr}$

$1,5 \% \mathrm{Cr}$

$2 \% \mathrm{Cr}$

Shaving wastes containing chromium are grinded and sterilized. Every substrate mixture having different chromium dosage is separated into 4 groups and study is conducted with 4 repetitions. Convenient substrate mixture for the growing of Pleurotus ostreatus is prepared in Bergama Technicial and Bussiness Collage, Ege University. Materials are weighed with predetermined weights by taking percentage of dry substance if their mixture substrate as basis, for the preparation of substrate. Then, mixtures are damped and humidity rate is accessed to $70 \%$.

\subsubsection{Sterilization and Mycelium Grafting}

Mixture substrate are pasteurized, after damping, by boiling in water $\left(70^{\circ} \mathrm{C}\right)$ for 2 hours. Substrate are left for cooling after pasteurization and $1 \%$ plaster over the basis of weight is added to all mixtures to adjust $\mathrm{pH}$ level. Temperature is rapidly decreased to nearly $25^{\circ} \mathrm{C}$, by draining excess water on the table possessing perforated grill with ventilation from the bottom. Growing mixtures with decreased temperatures are put into bags of $40 \times 50 \mathrm{~cm}$ dimensions, $2 \mathrm{~kg}$ of mixtures substrate being in each bag and inoculation is done, by homogenously mixing $2 \%$ of the weight of spawn suitable for inoculation. Bags which are inoculated with spawn are compressed and their openings are covered by fastening.

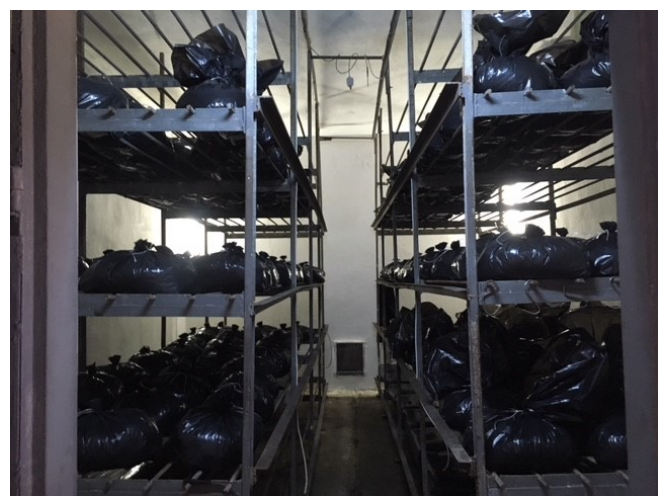

Figure 3. Fungus Growing Room and Pre-tests.

\subsubsection{Incubation and Harvest}

Inoculated bags were incubated at $25^{\circ} \mathrm{C} \pm 2^{\circ} \mathrm{C}$ temperature and $70-80 \%$ humidity during incubation period ( 15 days) until mycelium colonized. Bags are perforated after full colonization, for the induce fructification. Temperature is adjusted to $15^{\circ} \mathrm{C} \pm 2^{\circ} \mathrm{C}$ in the production room to promote fungus formation, and the humidity is increased up to $85-90 \%$.

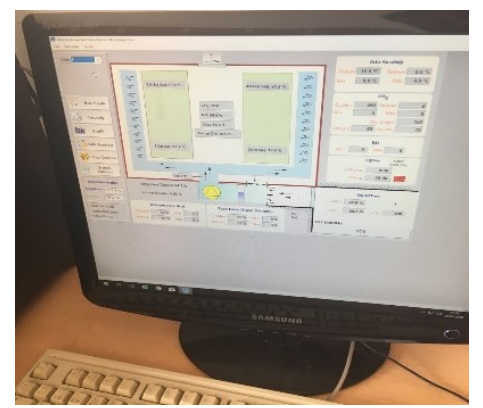

Figure 4. Monitoring system of fungus production room which adjusts required parameters for fungus development. 
12 hours of illumination with fluorescent lamps of 200 lux intensity is provided per day [Delmas and Mamoun, 1983]. Fresh air is supplied to the production room to promote primordium formation, and $\mathrm{CO}_{2}$ level is gradually decreased. Mushrooms are harvested by cutting with a knife after having reached a giving size. Chromium contents existing in the substrate and mushroom fruiting body are determined in "Argefar Lab., Ege University" through ICP-MS In House Method.

\subsubsection{Statistical Evaluation}

Tests related to mushroom development and yields are structured with 4 repetitions, 4 bags existing on each repetition, according to random plots test design [Düzgüneş et al., 1983]. Variance analyses of data obtained are done through SPSS (ver. 17.0 for Windows) statistical program and Duncan Test of Multiple Comparisons is used for groupings.

Wilcoxon Signed Ranks Test is applied to prove whether there is any difference or not on statistical meaning in chromium quantity within the mushroom and compost samples collected before the spawning of Pleurotus ostreatus and after the harvest [Özdamar, 2011].

Kruskal-Wallis Test is applied to prove whether there is any meaningful difference or not on determined $\mathrm{Cr}$ rates $(0,5 \%, 1 \%, 1,5 \%$ and $2 \%)$ [Özdamar, 2011].

\section{Results and Discussion}

Nitrogen content in shaving wastes containing chromium is determined as $14,18 \%$. Fungi of Pleurotus genus are cellulosic [Silva et al., 2012]. Even if nitrogen content may show a development on substrates which have a nitrogen content from $0,03 \%$ to 1,0\% [Machado et al., 2015], the best development is observed on $1,0 \%$ rate.

Addition to growing media of leather waste with chromium content is kept on rather low level due high $\mathrm{N}$ content. Correspondingly, $\mathrm{N}$ percentage content obtained from admixture substrate is given on Table 3.

Table 3. Composts possessing different chromium dosages.

\begin{tabular}{|c|c|}
\hline Substrate & $\mathbf{N}(\%)$ \\
\hline Control (C) & 0,84 \\
\hline $0,5 \%(\mathrm{Cr})$ & 1,02 \\
\hline $1,0 \%(\mathrm{Cr})$ & 1,17 \\
\hline $1,5 \%(\mathrm{Cr})$ & 1,27 \\
\hline $2,0 \%(\mathrm{Cr})$ & 1,44 \\
\hline
\end{tabular}

Mushroom development is determined during the research, on tests conducted on 5 different groups. It is observed that the mushroom has incorporated the chromium to its body and that chromium quantity is decreased in the environment when chromium quantity is examined before spawning after the preparation of compost and after the harvest. Arithmetic means of these values are seen on Table 4 whereas arithmetic means of chromium left in the compost before and after spawning are seen on Figure 5 . Chromium quantity existing in shaving waste containing chromium 
is also examined during tests and $42330 \mathrm{mg} / \mathrm{kg} \mathrm{Cr}$ content is determined in shaving waste through ICP-MS In House Method.

Table 4. Arithmetic means of $\mathrm{Cr}$ quantity left in the compost before and after mycelium inoculation and the one incorporated into the fungus fruiting body.

\begin{tabular}{|c|c|c|c|}
\hline $\begin{array}{c}\text { Compost } \\
\text { (wet blue } \\
\text { shaving } \\
\text { dust) }\end{array}$ & $\begin{array}{c}\text { Before Pleurotus } \\
\text { ostreatus spawn } \\
\text { inoculation (mean) } \\
\text { (media) (Cr) }\end{array}$ & $\begin{array}{c}\text { After Pleurotus } \\
\text { ostreatus harvest } \\
\text { (mean) (media) } \\
(\mathrm{Cr})\end{array}$ & $\begin{array}{c}\text { (Cr) within } \\
\text { Pleurotus } \\
\text { ostreatus fruiting } \\
\text { body }\end{array}$ \\
\hline $\begin{array}{c}0 \% \\
\text { (Control) }\end{array}$ & $4,33 \mathrm{mg} / \mathrm{kg}$ & - & $0,122 \mathrm{mg} / \mathrm{kg}$ \\
\hline $0,5 \%(\mathrm{Cr})$ & $530 \mathrm{mg} / \mathrm{kg}$ & $177,8 \mathrm{mg} / \mathrm{kg}$ & $0,372 \mathrm{mg} / \mathrm{kg}$ \\
\hline $1 \%(\mathrm{Cr})$ & $724 \mathrm{mg} / \mathrm{kg}$ & $205,6 \mathrm{mg} / \mathrm{kg}$ & $0,361 \mathrm{mg} / \mathrm{kg}$ \\
\hline $1,5 \%(\mathrm{Cr})$ & $6374 \mathrm{mg} / \mathrm{kg}$ & $482,8 \mathrm{mg} / \mathrm{kg}$ & $0,568 \mathrm{mg} / \mathrm{kg}$ \\
\hline $2 \%(\mathrm{Cr})$ & $11690 \mathrm{mg} / \mathrm{kg}$ & $951,1 \mathrm{mg} / \mathrm{kg}$ & $0,422 \mathrm{mg} / \mathrm{kg}$ \\
\hline
\end{tabular}

Kruskal-Wallis test is applied to examine whether $\mathrm{Cr}$ rate affects or not the capacity of Pleurotus ostreatus to incorporate into its body the $\mathrm{Cr}$ existing in the compost. $\mathrm{H}_{0}$ is rejected according to test result obtained (Asymp. Sig. $<0.05$ ). This fact proves that $\mathrm{Cr}$ rates create an important difference from the statistical point of view, on the capacity of Pleurotus ostreatus to incorporate $\mathrm{Cr}$ into its body.

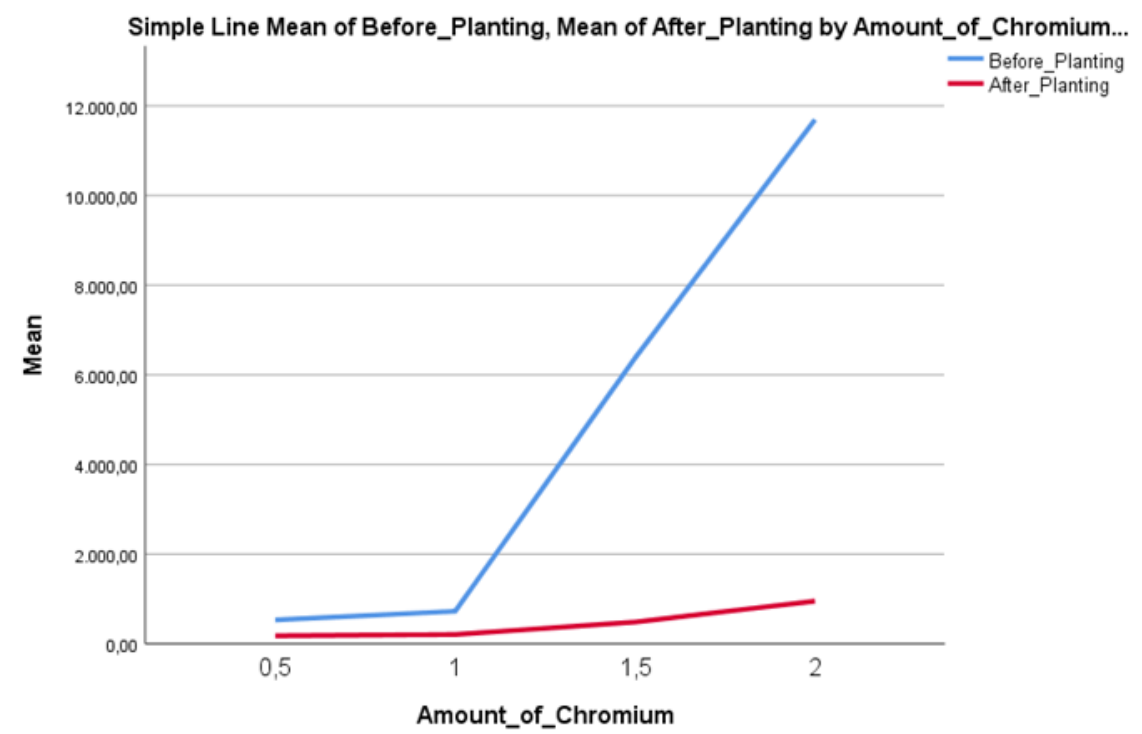

Figure 5. Statistical diagram graph of the chromium content in the media- before mycelium inoculation and after the harvest. 


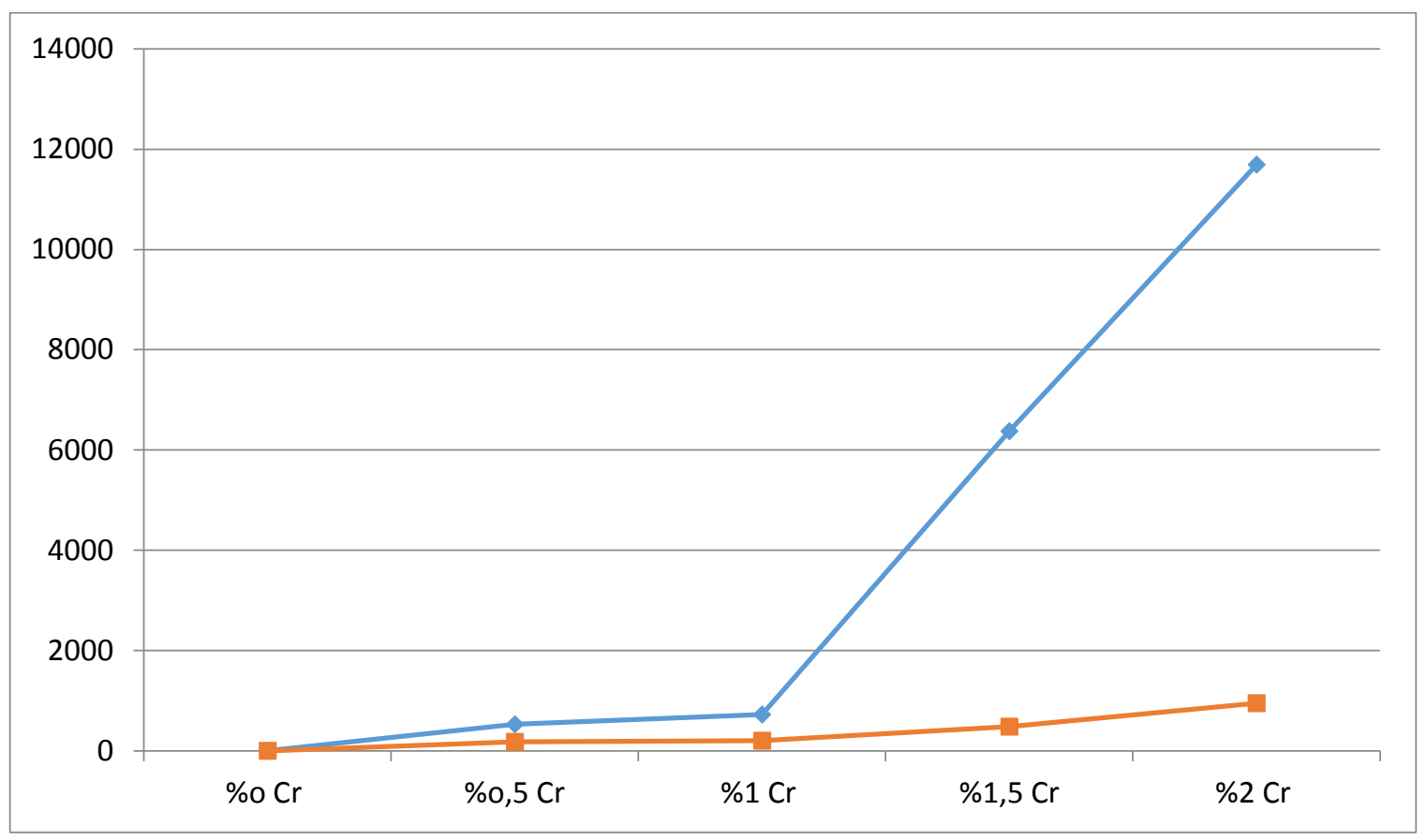

Figure 6. Arithmetic means diagram of $\mathrm{Cr}$ quantity left in the compost before mycelium inoculation and after the harvest.

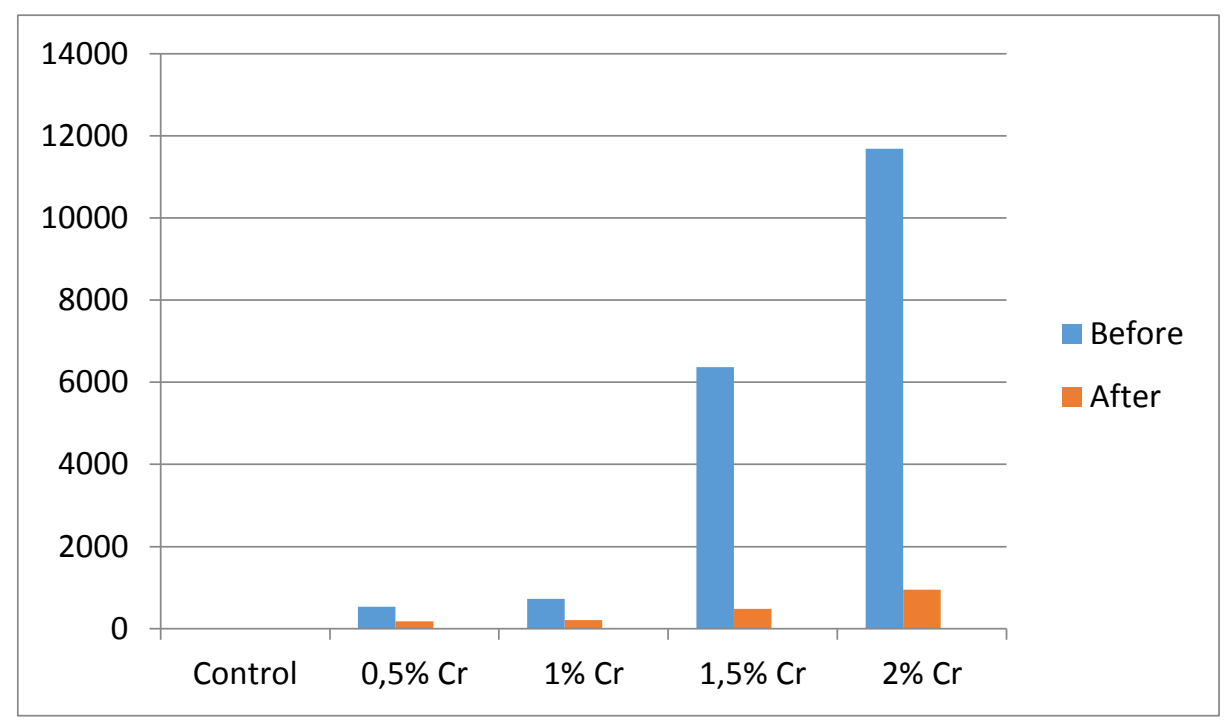

Figure 7. Chromium quantity left in the compost before the mycelium inoculation and after the harvest.

Under analyses done, it has been determined that Pleurotus ostreatus, while uptake into its body the chromium from convenient growing media containing shaving waste with different chromium rates, achieves the highest rate when $1,5 \%$ is added to the compost (Figure 8 ). 


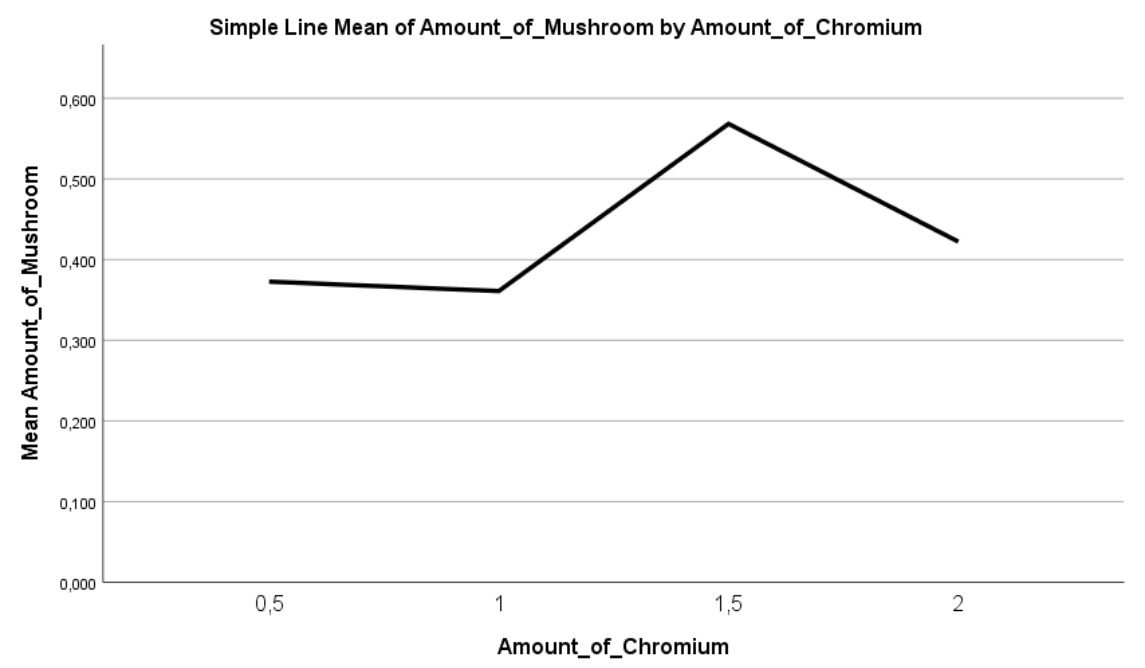

Figure 8. Uptake rate of chromium into the mushroom fruiting body.

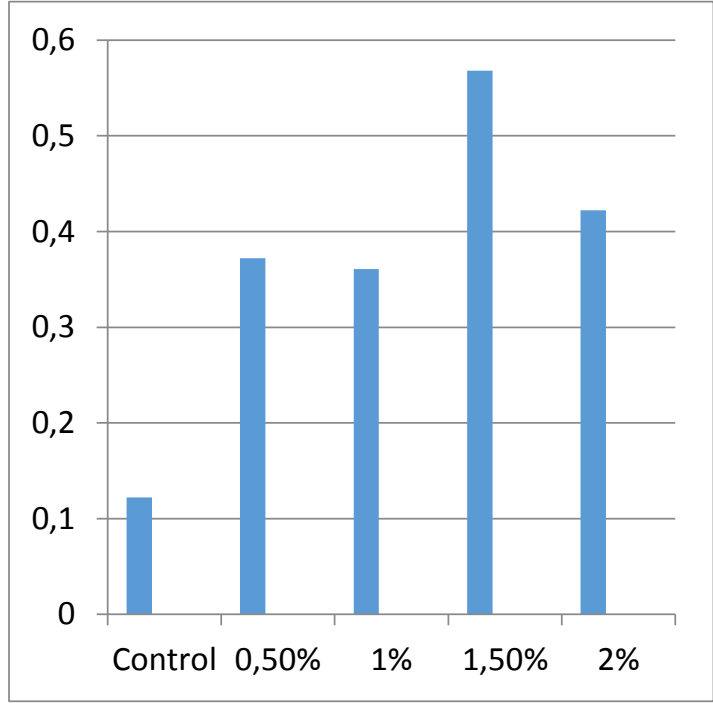

Figure 9. Chromium quantity the mushroom uptakes into its body in different compost contents.

The difference between compost mixed with shaving waste containing chromium with different rates and mushroom yield values obtained in the test conducted with the admixture substrate is determined as important statistically speaking. According to results of the study seen on Table 6 , whereas the highest yield is obtained from the compost to which 1,5\% shaving waste containing chromium is added $(214,81 \mathrm{~g} / \mathrm{kg}), 35 \%$ yield increase is observed when compared to the mixture (WS80+WB20) environment $(159,00 \mathrm{~g} / \mathrm{kg})$. The lowest yield is obtained from control application. Substrate where $0,5 \%, 1,0 \%$ and 2,0\% shaving waste containing chromium are included in the same group and yield increase of $14-26 \%$ is obtained when compared to the control [Yang et al., 2013]. Indicated that he obtained a yield of $214,6 \mathrm{~g} / \mathrm{kg}$ from the substrate he prepared with WS 80 (wheat straw) + WB20 (wheat bran). In another study, the yield of $P$. ostreatus in wheat straw growing media is indicated as $175 \mathrm{~g} / \mathrm{kg}$ compost [Yıldız et al., 1998] and 246,5 g/kg compost [Küçükomuzlu and Pekşen, 2005]. [Kurt and Büyükalaca, 2008] indicated through the study conducted, the highest yield obtained from 2 WS (wheat straw) + WB (wheat bran) media $(300,24 \mathrm{~g} / \mathrm{kg}$ ). It can be observed that yield values obtained in this study are coherent with data of these researchers. 
Table 5. Physical measurements of mushroom grown in different compost contents.

\begin{tabular}{|c|c|c|c|c|c|}
\hline Substrate & $\begin{array}{l}\text { Yield } \\
\text { (g/kg) }\end{array}$ & $\begin{array}{l}\text { Quantity of } \\
\text { mushroom } \\
\text { (pcs/kg) }\end{array}$ & $\begin{array}{c}\text { Cap } \\
\text { Diameter } \\
(\mathrm{mm})\end{array}$ & $\begin{array}{c}\text { Stalk } \\
\text { Diameter } \\
(\mathrm{mm})\end{array}$ & $\begin{array}{l}\text { Stalk } \\
\text { Length } \\
(\mathrm{mm})\end{array}$ \\
\hline $\begin{array}{l}\text { Control (Mixture) } \\
\text { (WS80+WB20) (0\%) }\end{array}$ & ${ }^{*} 159^{b}$ & ${ }^{*} 20,69^{b}$ & $69,43^{\text {ns }}$ & $9,71^{\mathrm{ns}}$ & $24,08^{\text {ns }}$ \\
\hline $0,5 \% \mathrm{Cr}+99,5 \%$ Mixture & $195,69^{b}$ & $30,25^{\mathrm{a}}$ & 68,26 & 9,54 & 21,13 \\
\hline 1,0\% Cr+99\% Mixture & $200,06^{\mathrm{ab}}$ & $33,20^{\mathrm{a}}$ & 75,06 & 10,00 & 19,38 \\
\hline 1,5\% $\mathrm{Cr}+98,5 \%$ Mixture & $214,81^{a}$ & $33,44^{a}$ & 74,17 & 9,92 & 24,29 \\
\hline 2,0\% $\mathrm{Cr}+98 \%$ Mixture & $180,81^{\text {ab }}$ & $30,50^{\mathrm{a}}$ & 69,12 & 10,46 & 24,42 \\
\hline
\end{tabular}

Asterisks indicate significance at $* P<0.05$, ns not significant; values within the same column followed by the same letter are not significantly different according to Duncan test.

In another study, it is indicated that high $\mathrm{N}$ quantity caused yield decrease on Pleurotus types [Desrumeaux et al., 2003]. Concordantly, yield value obtained in the study from 2.0 shaving containing chromium, where $\mathrm{N}$ content is higher indicated a decrease when compared to yield values obtained from substrates prepared with other shavings containing chromium.

The difference between the quantity of caps obtained from compost media mixed with different rates of shaving waste containing chromium and the test conducted with the control media is determined as important statistically speaking. When Table 5 is examined and concerning the quantity of caps obtained during the test from different compost media, the highest quantity of caps $(33,44$ pieces) is obtained from the substrate where $1,5 \%$ shaving containing chromium is added (Figure 8 ). Then we have substrates where $1 \%(33,20$ pieces), $2 \%(30,50$ pieces) and $0,5 \%$ $(30,25$ pieces) shaving containing chromium is added respectively. All substrates where shaving containing chromium is added are included in the same group. The lowest quantity of caps is obtained from the control media with 20,69 pieces.

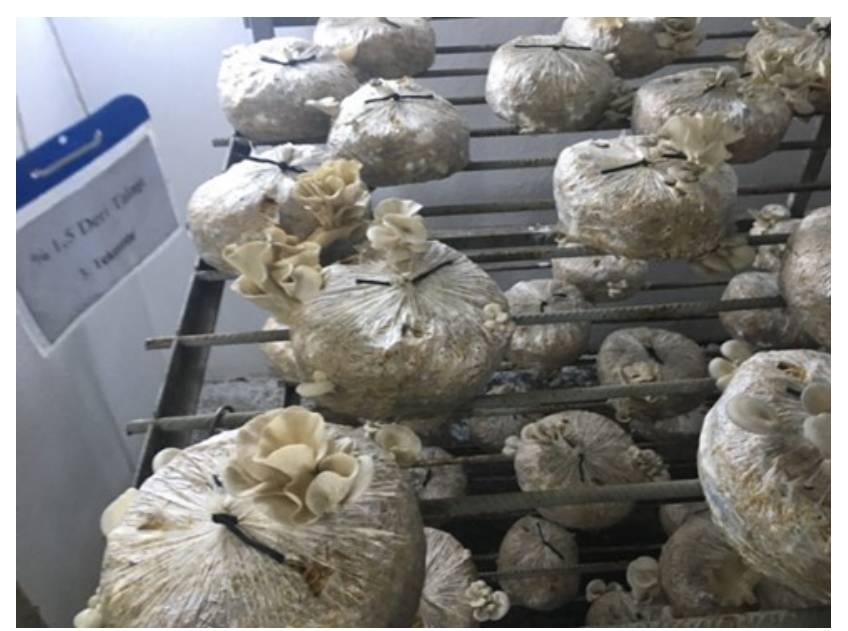

Figure 8. Mushroom which are grown in mushroom production room, developed in compost media with $1,5 \%$ chromium dose and which are available for harvest.

Differences among values concerning cap diameter, stalk diameter and stalk length are not considered as important. 


\section{Conclusion}

It has been understood through the study that Pleurotus ostreatus can easily develop and grow on leather shaving waste containing chromium and mineralize the chromium element by incorporating it in a certain extent into its body, when optimum conditions are provided. An important difference is determined in the quantity of chromium in the compost concerning composts prepared by adding different doses shaving waste containing chromium. The existence of chromium in the compost did not create any question in Pleurotus ostreatus growing from the stand point of mushroom development. On the contrary, a yield increase is observed due nitrogen existing in leather shaving waste containing chromium. However, though nitrogen rate is the highest in the compost having $2 \%$ rate of shaving waste containing chromium, the yield and chromium absorption are not at the maximum rate. As a reason we may say that high rate of nitrogen creates a negative impact for the development of Pleurotus ostreatus, and this point is coherent with the study of Desrumeaux et al., 2003.

When we compare both from the stand point of uptake of chromium to the body and high yield, most successful results are observed on fungi developed on the compost where 1,5\% shaving containing chromium is added.

It has clearly been determined as the result of our study that chromium does not have any negative impact for the development of Pleurotus ostreatus. Moreover, Pleurotus ostreatus, mineralizes the chromium by uptaking it to its body and decomposes it from the environment. We showed with this study that Pleurotus ostreatus can be used as mycoremediation in leather wastes containing chromium. Edibility of fungi obtained is the subject of another research. On the other hand, whether these mushroom can be used as fertilizer or animal feed should also be searched. The mushroom obtained can also be used for several different purposes as chromium source. This study conducted is a basic research which can light the way for many scientists.

\section{Acknowledgement}

The authors would like to thank to Ege University Scientific Research Project Department Directorate for the financial support they provided (Project No: 16-MUH-102). The authors also acknowledge the project of "Industrial Doctorate Program of Textile and Leather-2007 DPT 001" supported by T.R. Ministry of Development.

\section{References}

1. Argefar: Ege University, ICP-MS In House Method, EPA Methods 3051 Feb. 2007 and NMKL No:186, 2007

2. Bayramoğlu E.E., Önem E., Yorgancioglu A., Reduction of Hexavalent Chromium Formation in Leather with Various Natural Products (Coridothymus capitatus, Olea europaea, Corylus avellana and Juglans regia), Ekoloji, 114-120, 2012

3. Delmas, J. Mamoun, M.: Le Pleuroteen Corne D'abondance un Champignon Aujourd'hui Cultivable en France, P.H.M.-Revue Horticóule, 240, 39-46, 1983

4. Desrumaux B., Sedeyn P., Desmedt H., Lannoy, P., Leennegt, L.: Addition of Intact Corn Grain Before Pasteurization to Oyster Mushroom Substrate (Pleurotus spp.), Horticultural Abstracts, 73(5):47-61, 2003

5. Düzgüneş, O., Kesici, T. ve Gürbüz, F.,: İstatistik metotları I, Ankara Üniversitesi Ziraat Fakültesi yayınları, no: 861, Ders Kitabı, Ankara, 1983

6. Environmental Agency (EA). Reporting the Evidence: Dealing with Contaminated Land in England and

7. Wales. A Review of Progress from 2000-2007 with Part 2A of the Environmental Protection Act. Available online: https://www.gov.uk/government/uploads/system/uploads/ttachment_data/file/313964/geho0109bpha-e-e.pdf (accessed on 1 January 2015)

8. Environmental and Water Resources Institute (U.S.).: Natural Attenuation Task Committee, Natural attenuation of hazardous wastes, American Society of Civil Engineers, USA, 2004

9. Europian Commision, JRC Reference Reports: BAT Reference Document for the Tanning of Hides and Skins. Ispanya: Lüksemburg Avrupa Birliği Ofisi, 2013 
10. International Union of Leather Technologists and Chemists Societies, IUR - 1, 2013

11. Kunamneni, A., Ghazi I., Camarero, S., Ballesteros, A., Plou, F.J., Alcalde, M.: Decolorization of Synthetic Dyes by Laccase Immobilized on Epoxyactivatedcarriers, Process Biochemistry, 43(2), 169-178, 2008

12. Kurt, Ş and Büyükalaca, S.: Değişik Tarımsal Atıkların Pleurotus ostreatus Yetiştiriciliğinde Kullanım Olanaklarının Araştırılması, Türkiye VIII. Yemeklik Mantar Kongresi, 2008

13. Kurt, Ş.: Değişik Tarımsal Artıkların Kayın Mantarı (Pleurotus Ostreatus, Pleurotus Sajor-Caju) Yetiştiriciliğinde Kullanım Olanakları, Çukurova Üniversitesi Fen Bilimleri Enstitüsü, 2008

14. Küçükomuzlu, B., Pekşen, A.: Yetiştirme Ortamı Ağırlıklarının Pleurotus mantar Türlerinin Verim ve Kalitesi Üzerine Etkileri, OMÜ Zir. Fak. Dergisi, 20(3):64-71, 2005

15. Machado, A.R.G., Teixeira, M.F.S., Kirsch, L.S., Campelo, M.C.L., Oliveira, I.M.A.: Nutritional Value and Proteases of Lentinus Citrinus Produced by Solid State Fermentation of Lignocellulosic Waste from Yropical Region. Saudi J. Biol. Sci., 2015

16. Nitrogen 4500-Norg-C Semi micro Kjeldahl "Standard Methods" for the Examination of Water and Wastewater, APHA 19th Edition, Washington 1995

17. Özdamar,K.,:Paket Programlar ile istatiksel Veri Analizi-1, MINITAB 15- PASW 18, 8.Baskı, 2011

18. Pease, E.A., Aust, S.D., Tien, M.: Heterologous Expression of Active Manganese Peroxidase From Phanerochaete Chrysosporium Using The Baculovirus Expression System. Biochemical and Biophysical Research Communications, 179, 897-903, 1991

19. Shukla, D.P., Mishra A.Y., Vaghela K.B., Jain, N.K.: Eco-Friendly Approach for Environment Pollution: A Review on Bioremeditaion, 6956-6961, 2017

20. Silva, M.C.S, Naozuka, J., da Luz, J.M.R., de Assunçao, L.S., Oliveria, P.V., Vanetti, M.C.D., et al,: Enrichment of Pleurotus ostreatus Mushrooms with Seleniumin Coffe Husks. Food Chem. 131, 558-563, 2012

21. Ünal Z.B, and YIImaz S.: Environmental Damages Of Textile Industry And Its Role in the Global Climate Change XII th International Izmir Textile And Apparel Symposium, 2015

22. Yang, W.J., Guo, F.L., Wan, Z.J.: Yield and Size of Oyster Mushroom Grown on Rice/Wheat Straw Basal Substrate Supplemented with Cotton Seed Hull. Saudi Journal of Biological Sciences, 20, 333-338, 2013

23. Yeşilada, Ö.: Decolorization of Crystal Violet by Fungi, World Journal of Microbiology and Biotechnology, 11, 601-602, 1995

24. Yıldız, A., Karakaplan, M., Aydın, F.: Studies on Pleurotus ostreatus (Jacq. ex Fr.) Kum Var. Salignus (Pers ex. Fr.) Konr. Et Maubl.: Cultivation, Proximate Composition, Organic and Mineral Composition of Carpophores. Food Chemistry, $61(1 / 2): 127-130,1998$

25. (http://www.mneproje.com/public/website/news/deri-sanayinde-krom-geri-kazanimi_20180924031547.pdf)-22.05.2019

26. Yılmaz S. and Özgün S.: Recycling Possibility Of Buildings Destroyed In The Last 5 Years Due To Terror In Turkey And The Warln Syria. European Scientific Journal, 47-55, 2016 